\title{
Methanogenic community composition and anaerobic carbon turnover in submarine permafrost sediments of the Siberian Laptev Sea
}

\author{
Katharina Koch, ${ }^{1 *}$ Christian Knoblauch ${ }^{2}$ and \\ Dirk Wagner ${ }^{1}$ \\ ${ }^{1}$ Alfred Wegener Institute for Polar and Marine \\ Research, Research Department Potsdam, \\ Telegrafenberg A45, 14473 Potsdam, Germany. \\ ${ }^{2}$ Institute of Soil Science, University of Hamburg, \\ Allende-Platz 2, 20146 Hamburg, Germany.
}

\section{Summary}

The Siberian Laptev Sea shelf contains submarine permafrost, which was formed by flooding of terrestrial permafrost with ocean water during the Holocene sea level rise. This flooding resulted in a warming of the permafrost to temperatures close below $0^{\circ} \mathrm{C}$. The impact of these environmental changes on methanogenic communities and carbon dynamics in the permafrost was studied in a submarine permafrost core of the Siberian Laptev Sea shelf. Total organic carbon (TOC) content varied between $0.03 \%$ and $8.7 \%$ with highest values between 53 and $62 \mathrm{~m}$ depth below sea floor. In the same depth, maximum methane concentrations $\left(284 \mathrm{nmol} \mathrm{CH}_{4} \mathrm{~g}^{-1}\right.$ ) and lowest carbon isotope values of methane $(-72.2 \%$ 。 VPDB) were measured, latter indicating microbial formation of methane under in situ conditions. The archaeal community structure was assessed by a nested polymerase chain reaction (PCR) amplification for DGGE, followed by sequencing of reamplified bands. Submarine permafrost samples showed a different archaeal community than the nearby terrestrial permafrost. Samples with high methane concentrations were dominated by sequences affiliated rather to the methylotrophic genera Methanosarcina and Methanococcoides as well as to uncultured archaea. The presented results give the first insights into the archaeal community in submarine permafrost and the first evidence for their activity at in situ conditions.

Received 22 July 2008; accepted 10 November 2008. *For correspondence. E-mail Katharina.Koch@awi.de; Tel. (+49) 331288 2162; Fax (+49) 3312882137.

\section{Introduction}

Arctic permafrost environments play an important role within the global methane cycle. Estimates of the methane emissions from these environments range between 10 and $39 \mathrm{Tg} \mathrm{a}^{-1}$ (Terragramm per anno), which represents up to $8 \%$ of the global methane emissions (Bartlett and Harriss, 1993; Cao et al., 1998). Methane contributes to about $18 \%$ of the actual increases in global warming via the so-called greenhouse effect (Forster et al., 2007), which may lead to long-term global climate change. Most warming occurs in high northern latitudes (Mann et al., 1999; Oldfield and Alverson, 2003). These regions are characterized by permafrost that underlay about $25 \%$ of the land surface (Zhang et al., 1999) and significant parts of the coastal sea shelves. Enormous quantities of carbon are stored in permafrost, which are by far larger than previously assumed (Anisimov and Reneva, 2006; Zimov et al., 2006). Currently most strongly discussed with reference to permafrost is therefore the question: 'What will happen to the carbon accumulated in permafrost, in the event of a climate change?' Recently published data show that an increase of the permafrost temperature in Siberian permafrost deposits would lead to substantial rise in microbially produced methane and carbon dioxide (Wagner et al., 2007). This is in accordance with updated model calculations predicting an increase of methane release for northern wetlands of up to $38 \%$ (Zhuang et al., 2004; Anisimov, 2007; Khvorostyanov et al., 2008).

Several studies demonstrate the presence of viable and cultivable microorganisms, including anaerobes, in terrestrial permafrost sediments up to 3 million years in age (Vainshtein et al., 1995; Shi et al., 1997; Rivkina et al., 1998; Gilichinsky et al., 2005). Although these environments are characterized by freezing temperatures, it was recently shown that the abundance and composition of the methanogenic population is similar to that of communities of similar temperate soil ecosystems (Wagner et al., 2005). Direct bacterial counts in the order of $10^{7}-10^{8}$ were reported for the active layer and the perennially frozen ground in north-east Siberia (Rivkina et al., 1998; Kobabe et al., 2004). Other studies reported only low numbers of 
methanogens for the Mallik gas hydrate production research well (Colwell et al., 2005; Mangelsdorf et al., 2005). Nevertheless, methanogenic archaea in permafrost environments are well adapted to the extreme environmental condition of their habitat (Morozova and Wagner, 2007). These microorganisms do not only survive under permafrost conditions, but also can sustain active metabolism under in situ conditions (Rivkina et al., 2004; Wagner et al., 2007).

A particular variety of Arctic permafrost is the submarine permafrost, which underlay the shallow shelves of the Arctic coastal areas such as the Laptev Sea in north-east Siberia. This permafrost was formed by flooding of terrestrial permafrost with ocean water during the Holocene sea level rise (Rachold et al., 2007). Flooding of the cold terrestrial permafrost $\left(-5\right.$ to $\left.-15^{\circ} \mathrm{C}\right)$ with relatively warm $\left(-0.5\right.$ to $\left.-2^{\circ} \mathrm{C}\right)$ saline sea water changed the system profoundly and resulted in a warming of the frozen sediments (Overduin, 2007), which might enable and enhance microbial carbon turnover. As the submarine permafrost originates from frozen terrestrial Holocene and Pleistocene deposits, the autochthonous microbial community is expected to be of terrestrial origin.

Due to its poor accessibility, studies on the microbial diversity and activity in submarine permafrost neither have been conducted by cultivation dependent methods nor by cultivation independent molecular approaches.
Therefore, the microbial abundance and diversity in the carbon-rich permafrost as well as the significance of microbial activity and response to rising temperatures is completely unknown. The purpose of this investigation was a basic characterization of methanogenic communities in submarine permafrost sediments from the Laptev Sea and its potential for carbon mineralization in the frozen sediments. A cultivation-independent approach was used based on denaturing gradient gel electrophoresis (DGGE) of sediment DNA followed by sequencing of reamplified DNA bands. Geochemical and stable carbon isotope data were collected from the submarine permafrost core to trace evidence for microbial activity in the permanently frozen terrestrial sediments under the sea floor.

\section{Results}

Characteristics of the submarine permafrost sediments

The total organic carbon (TOC) content, methane concentrations and stable carbon isotope ratios of methane and TOC were measured in samples from the frozen part of the retrieved sediment core between 40.5 and $63.4 \mathrm{mbsf}$ (metres below sea floor) (Fig. 1), representing submarine permafrost deposits. Generally, analysed parameters showed minor variations in the upper part of the core
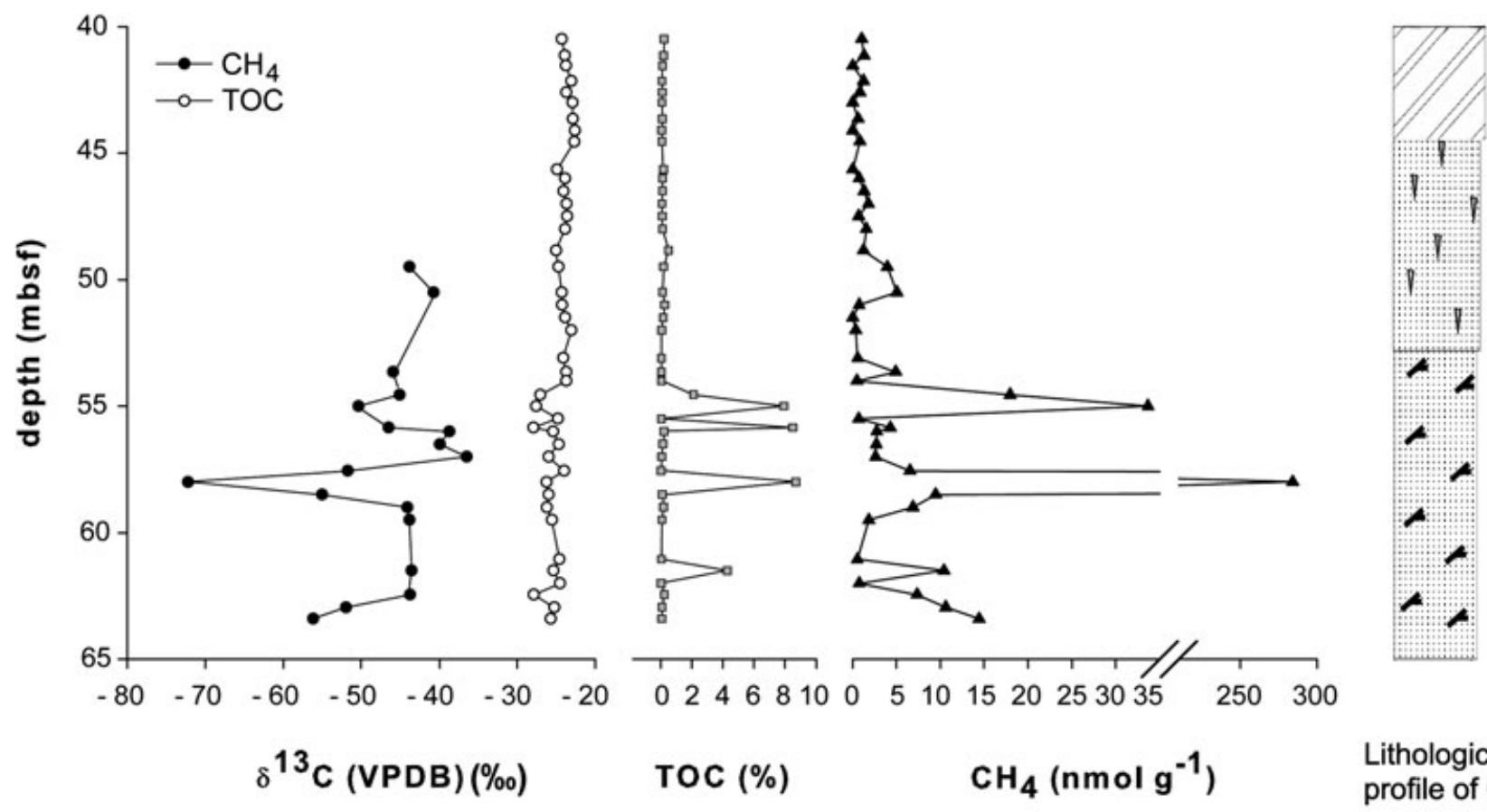

TOC (\%)

$\mathrm{CH}_{4}\left(\mathrm{nmol} \mathrm{g}^{-1}\right)$

Lithological profile of C2

\section{Clayed fine sand brownish grey [I Fine sand brownish grey $\lambda$ Medium to fine sand brownish grey}

Fig. 1. Vertical profiles of $\delta^{13} \mathrm{C}$ values of methane and soil organic carbon as well as concentrations of total organic carbon (TOC), methane and cross-section of the submarine permafrost sediments according to Overduin (2007, modified) 
(40-53 mbsf) but differed stronger in the deeper part (53$64 \mathrm{mbsf})$. The TOC content varied between $0.03 \%$ and $8.7 \%$ in depths between 40.5 and $63.4 \mathrm{mbsf}$ with the highest concentration at 58 mbsf. Elevated TOC concentrations were also found at depths of 55, 55.9 and 61.5 mbsf. Methane concentrations varied strongly $\left(0-284 \mathrm{nmol} \mathrm{g}^{-1}\right)$ with two distinct peaks at 55 and $58 \mathrm{mbsf}$. The $\delta^{13} \mathrm{C}$ values of TOC ranged between $-23.1 \%$ and $-27.9 \%$ 。PDB with generally lower values in the deeper part of the core where also elevated TOC and methane concentrations were measured. Due to the small sample size $\delta^{13} \mathrm{C}$ values of methane could only be determined if dissolved $\mathrm{CH}_{4}$ concentrations were above $2 \mathrm{nmol} \mathrm{g}^{-1}$, which was the case in core depths below 49 mbsf. Methane $\delta^{13} \mathrm{C}$ values ranged between $-36.5 \%$ 。 and $-72.2 \%$. VPDB with the lowest values in the zone of highest methane and TOC concentrations.

\section{DGGE analysis of submarine permafrost sediments}

Community analyses with specific primers for methanogenic Archaea were accomplished to study a possible link between these microorganisms and the elevated methane concentration in the submarine permafrost sediments. The DGGE profile (Fig. 2) showed the presence of up to 34 bands along the submarine permafrost profile between 35 and $66.7 \mathrm{mbsf}$. The dissimilarity of these bands showed the occurrence of different archaea in every depth. Generally, the number of bands varied with depth. Only in the upper two layers between 35 and $43.1 \mathrm{mbsf}$ the number of bands was constant with about five bands. At least two well-defined bands were present in every depth apart from the depth of 50.6-50.7 mbsf (one well-defined band). Between 57.7 and $58.2 \mathrm{mbsf}$ up to seven different bands were detected showing a higher variability of methanogenic archaea in the sediments at this depth. In the depth between 57.7 and 58.2, where TOC and methane concentrations were highest and $\delta^{13} \mathrm{CH}_{4}$ values lowest, DGGE bands were considerably stronger than in the rest of the submarine permafrost core. At the depth from 52.6 to $52.7 \mathrm{mbsf}$ up to nine different bands were detected, but the intensities of all bands in this sediment layer were too weak to be exploited. Twenty-six sequences of the 16S rRNA gene fragments from submarine permafrost environments could be reamplified from the DGGE gel and were tested by the Ribosome Database Project II. Sequences could be assigned to the genera Methanosarcina (9 sequences), Methanococcoides (9 sequences), Methanoculleus (1 sequence) and Methanogenium (1 sequence). The similarity of all sequences to its closest relative varied between $98 \%$ and $99 \%$. Six sequences were affiliated with uncultured archaea (92-99\% similarity; Table 1).

Phylogenetic analysis of methanogenic sequences from submarine permafrost

A total of 34 DGGE bands were sequenced. Eight sequences were excluded from the further analysis because of their short length $(<230$ nucleotides). The remaining 26 sequences were used for the construction of a phylogenetic tree (Fig. 3). Every sequence (> 230 nucleotides) of a phylogenetic group was based on adding the sequences to archaeal phylogenetic trees of nearly fulllength 16S rRNA gene sequences. Eighteen sequences fell in the family Methanosarcinaceae, forming three new Submarine Permafrost Clusters. Nine sequences could be classified as members of the genus Methanosarcina and another nine as members of the genus Methanococcoides. One sequence from the depth of $58 \mathrm{mbsf}$ showing highest methane concentrations and the lowest methane $8^{13} \mathrm{C}$ values affiliated to the Permafrost Cluster I described by Ganzert and colleagues (2007). Furthermore, nine sequences, including two submarine permafrost clusters (II and III), were nearly identical to Methanococcoides

Table 1. Archaeal species detected by PCR-DGGE from different study sites in north-east Siberia.

\begin{tabular}{|c|c|c|c|c|}
\hline Taxonomic units & Genus & $\begin{array}{l}\text { Submarine permafrost } \\
\text { sediments, Laptev Sea shelfa }\end{array}$ & $\begin{array}{l}\text { Permafrost-affected soils, } \\
\text { Laptev Sea region }{ }^{\mathrm{b}}\end{array}$ & $\begin{array}{l}\text { Late Pleistocene permafrost } \\
\text { sediments, Lena Delta }{ }^{c}\end{array}$ \\
\hline \multirow[t]{2}{*}{ Methanosarcinaceae } & Methanosarcina & 9 & 11 & 2 \\
\hline & Methanococcoides & 9 & - & - \\
\hline \multirow[t]{3}{*}{ Methanomicrobiaceae } & Methanogenium & 1 & - & - \\
\hline & Methanoculleus & 1 & - & - \\
\hline & Others & - & 12 & 10 \\
\hline Methanosaetaceae & Methanosaeta & - & 2 & 2 \\
\hline Crenarchaeota & & n.d. & n.d. & 10 \\
\hline Uncultured Archaea & & 6 & 3 & - \\
\hline Sequences (total) & & 26 & 28 & 24 \\
\hline
\end{tabular}

a. This study.

b. Ganzert and colleagues (2007).

c. G. Jurgens and D. Wagner, unpubl. data.

n.d., not determined. 


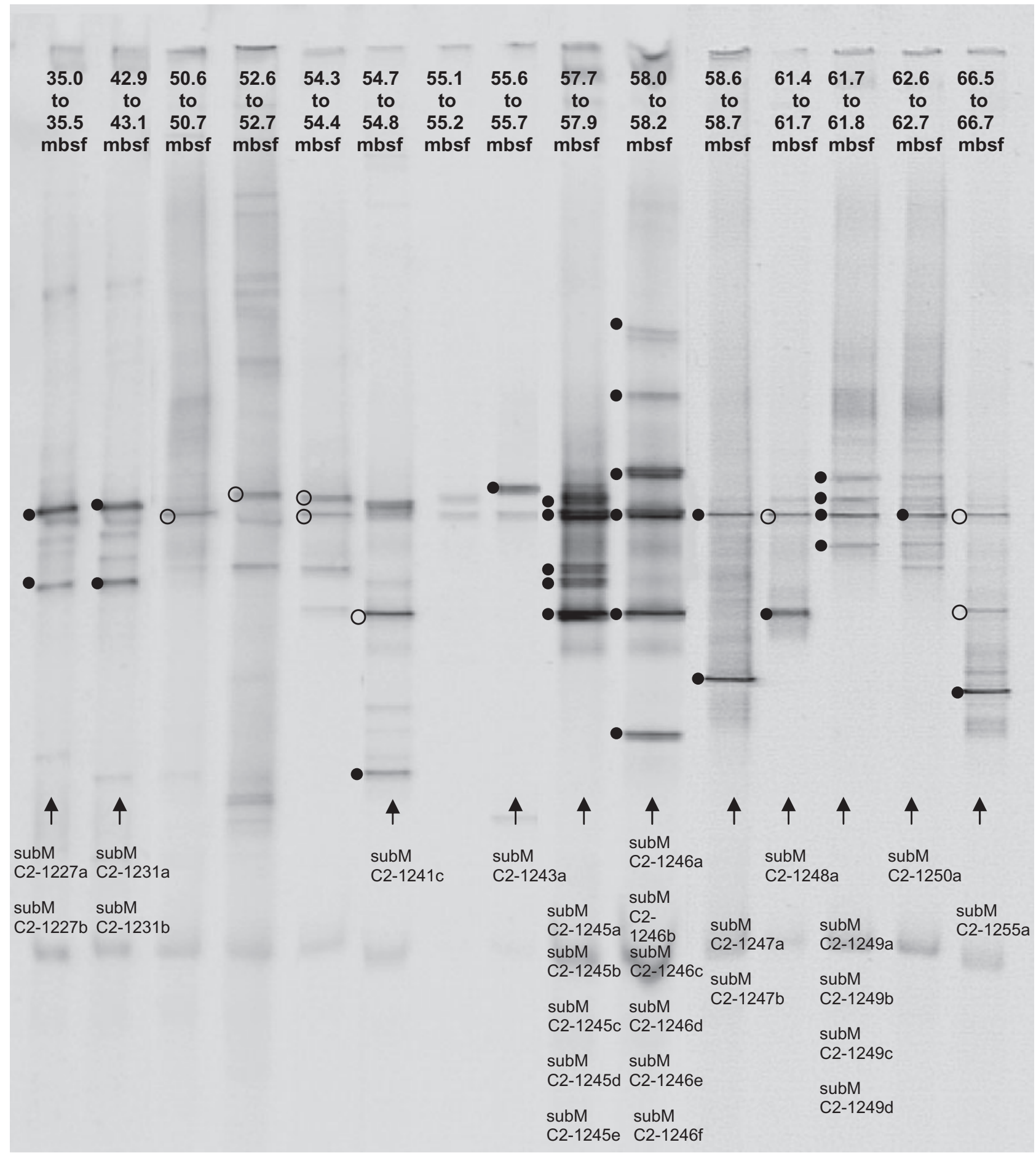

Fig. 2. DGGE profiles of $16 S$ rRNA genes amplified from submarine permafrost community DNA obtained from various depths of the sediments between 35 and 66.7 mbsf. Marked bands were selected for sequencing (black circles $\geq 230$ bp; open circle $\leq 230$ bp). Only sequences longer than 230 bp were used for phylogenetic analysis.

burtonii from Ace Lake, Antarctica. Two more sequences (subM_C2_1247b and subM_C2_1255a) belonged to the order Methanomicrobiales and the remaining six to unidentified Archaea. Four of them constitute the fourth new
'Submarine Permafrost Cluster'. Sequences assigned to Methanococcoides were found in deeper submarine permafrost sediments (55.6-62.7 m), whereas sequences associated with Methanosarcina were mainly observed in 


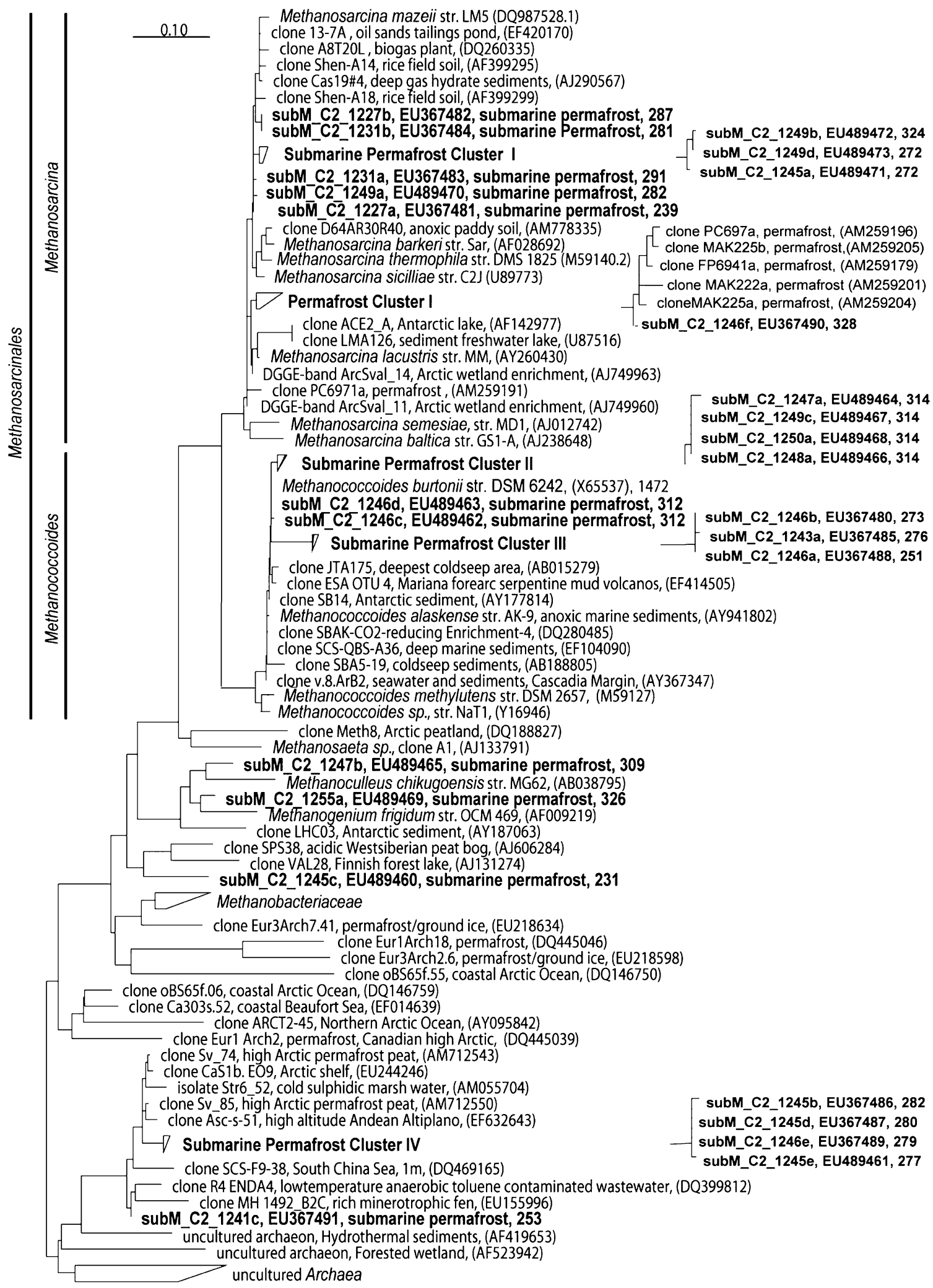

Fig. 3. Phylogenetic analysis (maximum likelihood) illustrating the affiliation of methanogenic $16 \mathrm{~S}$ rRNA gene sequences reamplified from DGGE bands. The sequences recovered from submarine permafrost belong to Methanosarcina, Methanococcoides, Methanomicrobiales and uncultured archaea. The scale bar represents 0.10 changes per nucleotide. Identification of the bands is shown in Fig. 2. Environment, clone name, accession number and length of each sequence are indicated. 
the top and bottom of the submarine permafrost sediments. Most of the sequences related to uncultured archaea were found in the zone with maximum methane concentration.

\section{Discussion}

Permafrost ecosystems of the Siberian Arctic are characterized by low in situ temperatures and high water contents, which leads to the accumulation of organic carbon. The fate of this carbon reservoir is of particular interest, considering possible feedback mechanisms that might result in increasing methane fluxes in a warming Arctic. Submarine permafrost, which was warming to near $0^{\circ} \mathrm{C}$ after being flooded by marine waters, is a natural laboratory for studying the impact of environmental changes on microbial decomposition processes. This study presents the first results on the methanogenic community composition and evidence for methanogenic activity in submarine permafrost sediments.

Our results show a distinct methane profile along the Late Pleistocene deposits with trace amounts in the upper part of the frozen sediments, maximum values in two distinct peaks between about 53 and $63 \mathrm{mbsf}$ and again low methane concentrations at the bottom of the profile. The two methane peaks between 53 and $63 \mathrm{mbsf}$ cannot be explained by an upward diffusion of methane from the unfrozen sediment layers as latter explanation would require high methane concentrations in the bottom of the sediment that, however, were not present. Water saturated and frozen sediment layers are an effective diffusion barrier preventing gas diffusion between the sediment layers. Rivkina and Gilichinsky (1996) and Rivkina and colleagues (2007) measured methane concentration profiles in different aged permafrost deposits of north-east Siberia. At several sites, they found elevated methane concentrations in deep $(20-50 \mathrm{~m})$ permafrost material but almost no methane in overlaying permafrost. They concluded from these results that methane cannot diffuse through frozen sediments. Furthermore, Cramer and Franke (2005) measured hydrocarbon concentrations and stable carbon isotope signatures in sea water and surface sediments of the NE Laptev Sea and found thermally generated methane seeping through the sediments only in the northern part of the Shelf. They concluded that the submarine permafrost layer in the central Laptev Sea is preventing hydrocarbons from being released into the sea water. As the methane profile in the investigated core gives no indication for vertical methane diffusion from below the frozen sediment and methane diffusion is impeded inside the frozen permafrost, we are confident that the high methane concentrations in the permafrost core at depths of 53 and $59 \mathrm{mbsf}$ are due to in situ methanogenesis. The potential for methane produc- tion in Holocene and Pleistocene permafrost deposits at subzero temperatures has already been shown in previous investigations (Rivkina et al., 2007; Wagner et al., 2007).

Further evidence that methane was indeed produced in situ is given by the profile of TOC. Maximum methane concentrations and highest TOC values of up to $8.7 \%$ were measured in the same sediment layers. As methane is the final end-product of anoxic organic matter degradation the elevated methane concentrations most likely originate from the high amount of organic matter in the same sediment layer. However, besides the amount of organic matter, also its availability for microbial degradation (Hogg, 1993; Wagner et al., 2007), as well as the distribution of methanogens along the sediment profile (Fig. 2), may explain the large variability of methane concentrations in the core profile (Fig. 1).

The stable carbon isotope signatures of methane in the studied core indicates conclusively that elevated methane concentrations in the deeper part of the core (Fig. 1) are of microbial origin. Methane produced during methanogenesis is strongly depleted in ${ }^{13} \mathrm{C}$ resulting in $\delta^{13} \mathrm{CH}_{4}$ values in the range of -55 to $-90 \%$ VPDB (Rice, 1992; Thomsen et al., 2001, Webster, 2005). The low $\delta^{13} \mathrm{CH}_{4}$ value of $-72.2 \%$ VPDB and the high methane concentration in a sediment depth of about 58 mbsf indicate that methanogenic archaea actively form methane at in situ temperatures of $-1.5^{\circ} \mathrm{C}$. Flooding of the terrestrial permafrost resulted in a significant temperature rise from $-12^{\circ} \mathrm{C}$ in the terrestrial permafrost to about $-1.5^{\circ} \mathrm{C}$ in the submarine permafrost (Rachold et al., 2007). The microbial degradation of the available organic matter in the submarine permafrost was most likely enhanced as a result of this post flooding temperature rise. This interpretation is in accordance with results from terrestrial Holocene permafrost deposits from the Lena Delta, indicating modern methanogenesis in the frozen ground by cold-adapted methanogens at temperatures as low as $-6^{\circ} \mathrm{C}$ (Wagner et al., 2007).

The DGGE profile of $16 \mathrm{~S}$ rRNA genes was used to study the distribution of methanogenic archaea along the submarine permafrost sediments and to get a deeper insight into the phylogenetic relationship of the methanogenic community in comparison to terrestrial permafrost deposits. The DGGE fingerprints showed significant differences within the depth profile of submarine permafrost. Particularly, the analysis revealed a more divers methanogenic population in the frozen sediments in a depth of around 58 mbsf. In this layer, up to 9 DGGE bands were found with a noticeable density in comparison to the other depths. This increased diversity is comparable with the diversity of methanogens within the active layer of permafrost soils from the same study region (Ganzert et al., 2007). 
Sequences obtained from the DGGE bands affiliated with Methanosarcinaceae, Methanomicrobiaceae and hitherto uncultured archaea, while species of the families Methanobacteriaceae and Methanosaetaceae, as reported in other studies on archaeal diversity in Arctic permafrost environments (Høj et al., 2005; Ganzert et al., 2007), were not detected. A total of 18 sequences out of 26 belonged to Methanosarcinaceae and only 2 sequences belonged to Methanomicrobiaceae. Further 6 sequences were affiliated with uncultured archaea. This result suggested that the methanogenic community in submarine permafrost prefer among other substrates $\mathrm{C} 1$ compounds such as methanol and methylated amines.

The phylogenetic analysis showed that nine of the Methanosarcinaceae-like sequences were related to the genus Methanosarcina and further nine sequences were affiliated with the genus Methanococcoides (Table 1). Previous studies of permafrost-affected soils from the Laptev Sea coast reported that about $50 \%$ of the detected sequences were related with the order Methanomicrobiales, which is characterized by hydrogenotrophic methanogens, while the remaining sequences mainly affiliated to Methanosarcina-like methanogens and uncultured archaea (Ganzert et al., 2007). However, on the other hand latter study did not find any sequences related to Methanococcoides (Table 1). Also data from Late Pleistocene permafrost sediments from the Lena Delta showed a dominance of Methanomicrobiales-related sequences, while sequences related to Methanococcoides were not detected (G. Jurgens and D. Wagner, unpubl. results, Table 1).

The observed differences between the microbial community composition in submarine permafrost (particularly in the zone of high methane concentration) and its terrestrial counterpart are particularly noteworthy, because submarine permafrost sediments developed by the flooding of terrestrial permafrost due to sea level rise or coastal erosion (Rachold et al., 2007). We therefore expected a similar composition of the microbial community in the submarine as in the terrestrial permafrost but found distinct differences. The difference in the methanogenic communities in both permafrost types indicate that the environmental changes affecting submarine permafrost as flooding of the coastal areas, possibly caused the observed variation in the microbial community structure.

The Methanococcoides-related sequences were found mainly in the submarine permafrost layer with the highest methane concentration. Moreover, in this zone sequences are accumulated, which are closely related to uncultured archaea. However, so far the genus Methanococcoides comprises three species; two of them were isolated from polar regions. Methanococcoides burtonii was isolated from the anoxic hypolimnion of the Ace Lake, Antarctica (Franzmann et al., 1992), and Methanococcoides alaskense was obtained from marine sediments from Skan Bay, Alaska (Singh et al., 2005). Both organisms are cold-adapted with a minimum temperature for growth of 1.7 and -2.3 respectively. This shows that at least Methanococcoides relatives can be active and grow under in situ temperature conditions of the submarine permafrost sediments.

Another reason for the dominance of Methanococcoides relatives might be the elevated sulfate concentration in the zone between 57.7 and $58.2 \mathrm{mbsf}$, which was 10 times higher (between 1.5 and $2 \mathrm{mmol} \mathrm{l}^{-1}$ sulfate; P. Overduin, pers. comm., 2008) in comparison to the sediment layers above and below the zone of highest methane concentration. If sulfate is present, sulfate reduction is the major catabolic process due to the higher affinity of sulfate reducers for hydrogen and acetate and a higher energy yield of sulfate reduction in comparison with methanogenesis (Winfrey and Zeikus, 1977; Schönheit et al., 1982; King, 1984). Under these conditions methanogenesis is very low (Franzmann et al., 1991; Senior et al., 1982) and only favoured if using competitive substrates like methanol or methylated amines (Oremland and Polcin, 1982; Ferdelman et al., 1997), as it is the case for Methanococcoides in this zone.

Six of the Methanosarcina-like sequences (subM C2_1227a, subM_C2_1227b, subM_C2_1231a, subM _ C2_1231b, subM_C2_1246f, subM_C2_1249a) clustered with cultured methanogens (e.g. Methanosarcina barkeri, Ms. thermophila) and several environmental sequences with the closest relatives from rice field soils (Ramakrishnan et al., 2001), freshwater-lake sediments (MacGregor et al., 1997) and gas hydrate sediments (Marchesi et al., 2001). One of these sequences (subM_C2_1246f) was most closely related to the Permafrost Cluster I isolated from the terrestrial permafrost of the Laptev Sea hinterland (Ganzert et al., 2007). The remaining three sequences (subM_C2_1245a, subM_C2_1249b, subM_ C2_1249d) form the Submarine Permafrost Cluster I, which are most closely related to clone Shen-A18 (Ramakrishnan et al., 2001) and clone D64AR30R40 (Peng et al., 2008) from rice field soils. One of the sequences in this cluster was recovered from the sediment layer with the highest methane concentration, while the remaining two sequences were obtained from the depth between 61.4 and 61.7 mbsf characterized by low concentration of organic carbon and methane.

The closest relative of the Methanococcoides-like sequences is Methanococcoides burtonii (Franzmann et al., 1992), a cold-adapted species isolated from the Ace Lake, Antarctica. Four sequences (subM_C2_1247a, subM_C2_1248a, subM_C2_1249c, subM_C2_1250a) form the Submarine Permafrost Cluster II, which were obtained from three different sediment layers (58.65, $61.70,62.60 \mathrm{mbsf}$ ) below the zone of maximum methane 
concentration. Further three sequences (subM C2_1243a, subM_C2_1246a, subM_C2_1246b) form the Submarine Permafrost Cluster III. Two of them originated from the zone of highest methane concentration and one from the layer above this zone. Additional two sequences (subM_C2_1246c, subM_C2_1246d) recovered also from the zone of maximum methane concentration belonging to the group of Methanococcoides.

Only two sequences (subM_C2_1255a) were affiliated with Methanomicrobiaceae. The closest relative to the first sequence subM_C2_1247b, obtained from the bottom of the submarine permafrost above the unfrozen sediments, is Methanoculleus chikugoensis isolated from paddy field soil in Japan (Dianou et al., 2001). The second sequence subM_C2_1255a, recovered from the sediment layer above the zone of highest methane concentration, is closest related to Methanogenium frigidum isolated from the Ace Lake, Antarctica (Franzmann et al., 1997).

The final six sequences, which were mostly recovered from the zone of highest methane concentration, were closest related to uncultured archaeal sequences (similarity between $91 \%$ and $99 \%$ ). Sequence subM C2_1245c was closest related to a sequence obtained from an acidic peat bog from Siberia (Jurgens et al., 2000). Sequence subM_C2_1241c was closest related to a sequence from a minerotrophic fen peatland in central New York State (Cadillo-Quiroz et al., 2008). The final four sequences (subM_C2_1245b, subM_C2_1245d, subM_ C2_1245e, subM_C2_1246e) form Submarine Permafrost Cluster IV.

The sequences that were assigned to the submarine permafrost clusters might include methanogenic archaea characterized by specific adaptation mechanisms maintaining their survival and metabolic activity under the harsh environmental conditions of the permafrost environment. Previous studies on the response of methanogenic archaea, isolated from Siberian permafrost-affected soils, against different environmental stress conditions, showed a remarkable resistance of these organisms against extreme low temperature (down to $-78^{\circ} \mathrm{C}$ ), high salinity (up to $6 \mathrm{M} \mathrm{NaCl}$ ), starvation (up to 3 months) and desiccation (up to 25 days; Morozova and Wagner, 2007). Obviously, permafrost environments force the adaptation of microbial communities to low temperature conditions with species, which have been untraced in temperate ecosystems so far.

In conclusion, this study has provided the first knowledge of the methanogenic community composition in submarine permafrost sediments from the Laptev Sea coast. The results indicated a dominance of methylotrophic methanogenic archaea, particularly in the zone with maximum methane concentration, low $\delta^{13} \mathrm{CH}_{4}$ values, and elevated sulfate concentrations (up to $2 \mathrm{mmol} \mathrm{I}^{-1}$ ), which is contrary to detected archaeal groups in previous studies on Siberian permafrost environments. The observed differences in the methanogenic community structure in submarine permafrost sediments in comparison to its terrestrial counterpart may result from the up to- $10^{\circ} \mathrm{C}$ higher in situ temperature of submarine permafrost. To understand the carbon dynamics in permafrost environments under changing environmental conditions, it is of particular interest to know how the changes in the microbial community structure affect the decomposition of organic carbon under anoxic conditions. Therefore, submarine permafrost is considered as an ideal natural laboratory to study the impact of changing environmental conditions, particularly increasing permafrost temperatures, on the structure and function of microbial communities in climate-sensitive permafrost habitats.

\section{Experimental procedure}

\section{Investigation area}

The studied core was retrieved from the Laptev Sea shelf near Cape Mamontovy Klyk, north-east Siberia $\left(73^{\circ} 42^{\prime} \mathrm{N}\right.$, $117^{\circ} 10^{\prime} \mathrm{E}$, Fig. 4). The investigation area is characterized by an Arctic climate, with low mean annual precipitation (less than $300 \mathrm{~mm}$ ), short summers and, long and very cold winters (Grosse, 2005). This climate leads to the development of the typical landscape in the terrestrial hinterland known as the Arctic tundra. The entire area is located within the zone of continuous permafrost (Rachold et al., 1996). In contrast to the temperature minimum measured in terrestrial permafrost of this region $\left(-13^{\circ} \mathrm{C}\right.$, Wagner et al., 2007), the average temperature in the submarine permafrost amounted to $-1.5^{\circ} \mathrm{C}$ (Rachold et al., 2007).

\section{Drilling program and sample communication}

During the COAST expedition in spring 2005 five sediment cores were drilled in a transect from the Laptev Sea coast at Mamontovy Klyk to the shallow Laptev Sea shelf $\left(73^{\circ} 42^{\prime} \mathrm{N}\right.$, $\left.117^{\circ} 10^{\prime} \mathrm{E}\right)$. The Laptev Sea shelf was selected as suitable area for the coastal drilling transect, because the region between Olenyek and Anabar River Delta was not influenced by fluvial waters and deltaic depositions (Overduin, 2007). The goals of the COAST expedition were to analyse geochemical processes related to the interactions between sea water and permafrost as well as the characterization of microbial processes and communities. Analyses were conducted to trace the transformation of unchanged terrestrial permafrost via offshore permafrost to submarine permafrost. Detailed data on drilling are presented elsewhere (Overduin, 2007; Rachold et al., 2007).

Five cores of up to $77 \mathrm{~m}$ length were drilled on the Laptev Sea shelf and the coast. Drilling was carried out using a drilling rig (URB-2A-2) with a hydraulic rotary pressure mechanism. Drilling was conducted dehumidified and without flushing so that the natural structure of the drill cores remained intact. The core segments were transported in frozen condition to the Alfred Wegener Institute in Bremer- 


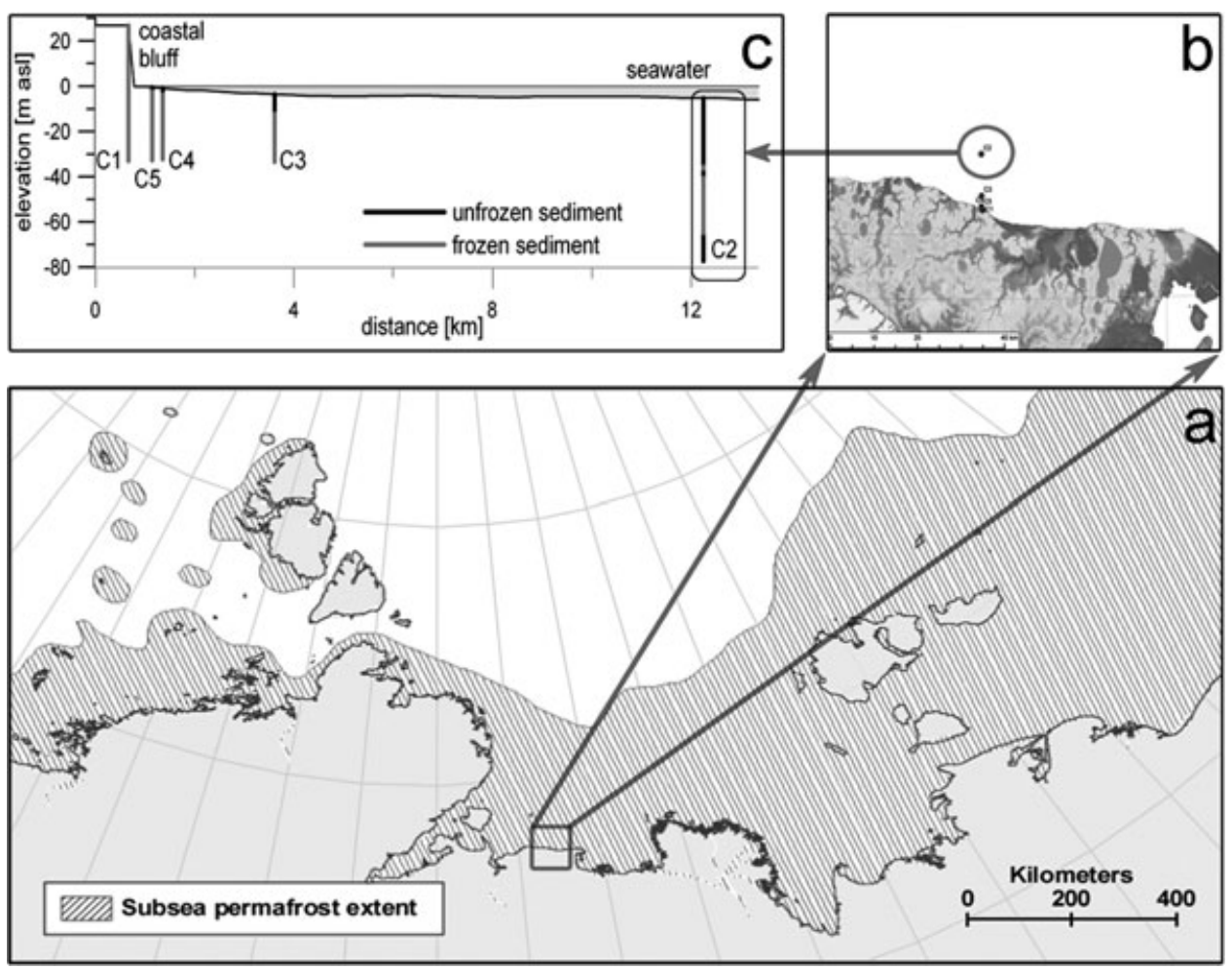

Fig. 4. (A) Investigation area of the Laptev Sea in north-east Siberia. (B) The right-handed small figure (with courtesy of G. Grosse, UAF) shows the exact position of submarine permafrost core 2 and (C) the left-handed figure shows its depth profile (Overduin et al., 2008, modified).

haven, Germany and archived at $-22^{\circ} \mathrm{C}$. Core segments from drill holes were split along their vertical axis into two halves under aseptic conditions with a diamond saw in an ice laboratory at $-15^{\circ} \mathrm{C}$. One half of each core was photographed and stored in a climatic room at $-22^{\circ} \mathrm{C}$ at the Alfred Wegener Institute for future reference. Afterward, the other half of the core was cleaned with a sterile knife for lithological and geocryologically descriptions (Overduin, 2007). Subsamples (small cylindrical pieces of approximately $10 \mathrm{~g}$ each) of each segment were extracted for analysis of the TOC and methane concentrations as well as stable carbon isotope signatures in the frozen sediments. The remaining material of each subsample was thawed at $4^{\circ} \mathrm{C}$ and homogenized under anoxic and sterile conditions for analysis of the microbial communities. Subsamples for the different analyses were filled into sterile plastic Nalgene boxes. Samples were used directly for the analyses or refrozen for later investigations at $-22^{\circ} \mathrm{C}$.

\section{Soil properties}

The core C2 (Fig. 4) was chosen for the current study. The drill site was most distant $(11.5 \mathrm{~km})$ from the coast. A channel temperature sensor was installed after drilling and the measured temperatures varied between $-1^{\circ} \mathrm{C}$ and $-1.7^{\circ} \mathrm{C}$. The depth of water was approximately $6.0 \mathrm{~m}$ with a sea ice thickness of $1.4 \mathrm{~m}$ and a bottom water salinity of $29.2 \%$. The drilling reached frozen sediment at a depth of $35.5 \mathrm{mbsf}$. As from approximately $36-40.3 \mathrm{~m}$ the sediment is again unfrozen and as well at depth 64.7 unfrozen sediments were discovered (P. Overduin, pers. comm.), the definitive upper permafrost boundary is still open to interpretation.

A precise description of the lithological profile of core C2 is given by Overduin (2007). Briefly, the sediments in all depths contain brownish and dark grey, fine sand. The sediments between 51.5 and 64.7 mbsf have found embedded deposits of dark plant and wood remains. The typical cryogenic structures of submarine permafrost deposits are visibly. The core age was determined for two selected samples with $86 \mathrm{ka}$ $(44.5 \mathrm{~m})$ and $111 \mathrm{ka}(77 \mathrm{~m})$ by IR-OSL at the Institute of Geology, Tallinn University of Technology, Research Laboratory for Quaternary Geochronology (A. Molodkov).

Vertical profiles of sediment $\mathrm{CH}_{4}$ concentrations were obtained from each segment by extracting $\mathrm{CH}_{4}$ from sediment porewater after thawing frozen subsamples (approximately $10 \mathrm{~g}$ ). The samples were placed in glass bottles ( $c$. $50 \mathrm{ml}$ ) containing $20 \mathrm{ml}$ of a saturated $\mathrm{NaCl}$ solution and sealed gas tight with black rubber stoppers. The thawed samples were shaken and the $\mathrm{CH}_{4}$ headspace concentration was analysed with gas chromatography. Subsequently, the stable carbon isotope composition of methane was determined.

For determining TOC and its stable carbon isotope signature subsamples were treated with $\mathrm{H}_{3} \mathrm{PO}_{4}$ overnight to remove inorganic carbon. Samples were subsequently washed repeatedly with distilled water to remove the remaining $\mathrm{H}_{3} \mathrm{PO}_{4}$. Samples were sieved $(<2 \mathrm{~mm})$, milled in a planetary ball mill, dried at $105^{\circ} \mathrm{C}$, and TOC was finally measured with an elemental analyser (Elementar VarioMAX). 


\section{Methane analysis}

Gas analysis was performed with an Agilent 6890 gas chromatograph equipped with a Carbonplot capillary column $(\varnothing$ $0.52 \mathrm{~mm}, 30 \mathrm{~m}$ ) and a flame ionization detector. Helium was used as the carrier gas. The injector, oven and detector temperatures were set at $45^{\circ} \mathrm{C}, 45^{\circ} \mathrm{C}$ and $250^{\circ} \mathrm{C}$ respectively. All gas sample analyses in the various experiments were done after calibration of the gas chromatograph with standard gases. After calibration the analytical reproducibility is $>98.5 \%$. Details of methane analysis were described previously in Wagner and colleagues (2003).

\section{Isotope measurement}

The $\delta^{13} \mathrm{C}$ values of particulate organic carbon were measured with an isotope ratio mass spectrometer (Finnigan Delta Plus) equipped with an elemental analyser (CE 2500) and a conflow II interface. Samples were calibrated against external standards (NBS 19, 1.95\%。VPDB; IAEA C6, 10.8\%。 VPDB; IVA soil standard $-27.46 \%$ VPDB). The $\delta^{13} \mathrm{C}$ values were expressed relative to the international VPDB standard.

Stable carbon isotope ratios of methane were determined at the same isotopic ratio mass spectrometer (Finnigan Delta Plus) equipped with a PreCon (Brand, 1995). Samples $(0.1-2 \mathrm{ml})$ were injected with a gas tight syringe (Hamilton) through a sample port into the sample container that was flushed with a constant flow $\left(20 \mathrm{ml} \mathrm{min}^{-1}\right)$ of $\mathrm{He}(>99.999 \%)$. The PreCon was used to remove $\mathrm{CO}_{2}$ from the samples, subsequently combust methane to $\mathrm{CO}_{2}$ at $1000^{\circ} \mathrm{C}$, and to concentrate the derived $\mathrm{CO}_{2}$ in two serial cryotraps at $-196^{\circ} \mathrm{C}$. The derived $\mathrm{CO}_{2}$ was transferred via a $\mathrm{GC}$ (Agilent 6890, Pora Plot Q column) and a GC/C III interface (Thermo, Bremen, Germany) to the mass spectrometer. ${ }^{13} \mathrm{C}$-isotope measurements of methane could only be conducted if concentrations were higher than about $2 \mathrm{nmol} \mathrm{g}^{-1}$. The reproducibility of the measurement was generally better than $\pm 0.5 \%$. Isotope values are given as $\delta^{13} \mathrm{C}(\%)$ calculated by the formula: $\delta^{13} \mathrm{C}=\left[\left(R_{\text {sample }} / R_{\text {standard }}\right)-1\right]$, with $R$ representing the ratio between ${ }^{13} \mathrm{C}$ and ${ }^{12} \mathrm{C}$ in the sample and the standard (VPDB $R=0.0112372$ ).

\section{Molecular analyses}

DNA was extracted from the submarine permafrost sediments using UltraClean ${ }^{\mathrm{TM}}$ Soil DNA Isolation Kit (Mo Bio Laboratories, Carlsbad, USA). Methanogenic 16S rRNA was amplified in a nested PCR protocol and analysed by DGGE. In the first amplification the primers ArUn4F (5'-TCY ggT TgA TCC TgC CRg-3') and Ar958R (5'-YCC ggC gTT gAV TCC AAT T-3') were used. In the second amplification the primer combination GC-357F and 0691R specific for methanogens (Watanabe et al., 2004) was applied to the identical DNA fragments. The reaction mixture of $50 \mu \mathrm{l}$ contained $1 \times$ PCR buffer, $0.25 \mathrm{mM}$ of each dNTP, $2 \mathrm{mM} \mathrm{MgCl}$, $0.4 \mu \mathrm{M}$ of each primer, 2.5 Unit HotStarTaq DNA Polymerase (Qiagen) and 1-2 $\mu$ l of template. The PCR cycle for the first amplification was $95^{\circ} \mathrm{C}$ in $10 \mathrm{~min}$ followed by 40 cycles of $94^{\circ} \mathrm{C}$ for $1 \mathrm{~min}, 57^{\circ} \mathrm{C}$ for $1 \mathrm{~min}$ and $72^{\circ} \mathrm{C}$ for $2 \mathrm{~min}$, followed by a final extension at $72^{\circ} \mathrm{C}$ for $10 \mathrm{~min}$. The fol- lowing PCR cycle was used for methanogenic amplifications: $95^{\circ} \mathrm{C}$ in $10 \mathrm{~min}$ followed by $30-35$ cycles of $94^{\circ} \mathrm{C}$ for $1 \mathrm{~min}, 53^{\circ} \mathrm{C}$ for $1 \mathrm{~min}$ and $72^{\circ} \mathrm{C}$ for $2 \mathrm{~min}$, followed by a final extension at $72^{\circ} \mathrm{C}$ for $10 \mathrm{~min}$. PCR was made using an iCycler Thermal Cycler (Bio-Rad). Electrophoresis was performed with $2 \%$ agarose gel in $0.5 \times \mathrm{TAE}$. Agarose gel was stained with SYBR Gold (1:10 000 dilution, Molecular Probes). Amplified fragments were separated on $8 \%$ polyacrylamide gels in 1.0 $\times$ TAE with a linear gradient of $30-55 \%$ [100\% denaturant was $7 \mathrm{M}$ urea and $40 \%(\mathrm{v} / \mathrm{v})$ formamide]. DGGE was performed at $60^{\circ} \mathrm{C}$ and $100 \mathrm{~V}$ for $840 \mathrm{~min}$. The gels were stained with SYBR Gold (1:10 000 dilution, Molecular Probes) for $30 \mathrm{~min}$, rinsed with distilled water and photographed under UV illumination. DGGE bands were cut from the gel using a sterile scapel, reamplified and PCR-purified as previously described (Ganzert et al., 2007). Sequencing was done by MWG Biotech AG (Martinsried, Germany).

\section{Phylogenetic analysis}

Sequences for methanogens were manually edited to get sequences (Sequencer 4.7, Gene Codes, USA), and contigs were assembled with the same program. Sequences for methanogens were tested using Ribosomal Database Project II (RDP, Taxonomic Outline of the Bacteria and Archaea, release 7.8, July 2007) and analysed using the BLAST tool at the National Center for Biotechnology Information (http://www.ncbi.nlm.nih.gov/blast/). Sequence and descriptive data for development of the ARB tree were downloaded from RDP (http://rdp.cme.msu.edu), EMBL (http://www.ebi.ac.uk), European rRNA Database (http:// bioinformatics.psb.ugent.be/webtools/rRNA/) and DSMZ (https://www.dsmz.de). The selected reference sequences were downloaded from NCBI/BLAST (http://www.ncbi. nlm.nih.gov/blast/Blast.cgi). Sequences for methanogens were added to a prealigned database using the aligning tools in the ARB program package (Technical University of Munich, Munich, Germany). The phylogenetic tree (maximum likelihood) was construced with filters termini and pos_var_arc_1450_aug04 and the Xfig software for tree view. All sequences determined in this study are edited with the software Sequin and deposited in the GenBank databases under accession number EU367469-EU367491 and EU489460-EU489473.

\section{Acknowledgements}

The authors wish to thank Volker Rachold (IASC, formerly Alfred Wegener Institute for Polar and Marine Research, Potsdam) for their leadership of the expedition COAST. Furthermore, we thank Dimitri V. Melnitschenko (Hydro Base Tiksi), Dimitry Yu. Bolshiyanov (Arctic and Antarctic Research Institute, St. Petersburg) and Waldemar Schneider (Alfred Wegener Institute for Polar and Marine Research, Potsdam) for their logistic support. The study is part of the GermanRussian project Dynamic and History of Permafrost, which was funded by the German Ministry of Education and Research (BMBF) and the Russian Ministry of Research and Technology. 


\section{References}

Anisimov, O.A. (2007) Potential feedback of thawing permafrost to the global climate system through methane emission. Environ Res Lett 2: 045016 (7pp).

Anisimov, O.A., and Reneva, S.A. (2006) Permafrost and changing climate: the Russian perspective. Ambio 35: 169-175.

Bartlett, K.B., and Harriss, R.C. (1993) Review and assessment of methane emissions from wetlands. Chemosphere 26: 261-320.

Brand, W.A. (1995) PreCon: a fully automated interface for the Pre-Gc concentration of trace gases on air for isotopic analysis. Isot Environ Health Stud 31: 277-284.

Cadillo-Quiroz, H., Yashiro, E., Yavitt, J.B., and Zinder, S.H. (2008) Characterization of the archaeal community in a minerotrophic fen and terminal restriction fragment length polymorphism-directed isolation of a novel hydrogenotrophic methanogen. Appl Environ Microbiol 74: 2059-2068.

Cao, M., Gregson, K., and Marshall, S. (1998) Global methane emission from wetlands and its sensitivity to climate change. Atmos Environ 32: 3293-3299.

Colwell, F.S., Nunoura, T., Delwiche, M.E., Boyd, S., Bolton, R., Reed, D., et al. (2005) Evidence of minimal methanogenic numbers and activity in sediments collected from the Mallik 5L-38 gas hydrate research well. In Geological Survey of Canada Bulletin 585. Dallimore, S.R., and Collett, T.S. (eds). Ottawa, Ontario, Canada: Geological Survey of Canada.

Cramer, B., and Franke, D. (2005) Indication for an active petroleum system in the Laptev Sea, NE Siberia. J Petrol Geol 28: 369-384.

Dianou, D., Miyaki, T., Asakawa, S., Morii, H., Nagaoka, K., Oyaizu, H., and Matsumoto, S. (2001) Methanoculleus chikugoensis sp. nov., a novel methanogenic archaeon isolated from paddy field soil in Japan, and DNA-DNA hybridization among Methanoculleus species. Int $J$ Syst Evol Microbiol 51: 1663-1669.

Ferdelman, T.G., Lee, C., Pantoja, S., Harder, J., Bebout, B.M., and Fossing, H. (1997) Sulfate reduction and methanogenesis in a Thioploca-dominated sedimentoff the coast of Chile. Geochimica Cosmochimica Acta 61: 30653079.

Forster, P., Ramaswamy, V., Artaxo, P., Berntsen, T., Betts, R., Fahey, D.W., et al. (2007) Changes in atmospheric constituents and in radiative forcing. In: Climate Change 2007: the Physical Science Basis. Contribution of Working Group I to the Fourth Assessment Report of the Intergovernmental Panel on Climate Change. Solomon S., Qin D., Manning M., Chen, Z., Marquis, M., Averyt, K.B., Tignor, M., et al. (eds). Cambridge, UK: Cambridge University Press, pp. 129-234.

Franzmann, P.D., Roberts, N.J., Mancuso, C.A., Burton, H.R., and McMeekin, T.A. (1991) Methane production in meromictic Ace Lake, Antartica. Hydrobiologia 210: 191201.

Franzmann, P.D., Springer, N., Ludwig, W., De Macario, E.C., and Rohde, M. (1992) A methanogenic archaeon from Ace Lake, Antarctica - Methanococcoides burtonii sp. nov. Syst Appl Microbiol 15: 573-558.
Franzmann, P.D., Liu, Y., Balkwill, D.L., Aldrich, H.C., Conway de Macario, E., and Boone, D.R. (1997) Methanogenium frigidium sp. nov., a psychrophilic, $\mathrm{H}_{2}$-using methanogen from Ace Lake, Antarctica. Int J Syst Bacteriol 47: 1068-1072.

Ganzert, L., Jurgens, G., Münster, U., and Wagner, D. (2007) Methanogenic communities in permafrost-affected soils on the Laptev Sea coast, Siberian Arctic, characterized by 16S rRNA gene fingerprints. FEMS Microbiol Ecol 59: 476488.

Gilichinsky, D., Rivkina, E., Bakermans, C., Shcherbakova, V., Petrovskaya, L., Ozerskaya, S., et al. (2005) Biodiversity of cryopegs in permafrost. FEMS Microbiol Ecol 53: 117-128.

Grosse, G. (2005) Characterisation and evolution of periglacial landscapes in Northern Siberia during the Late Quaternary - Remote sensing and GIS studies. Dissertation Thesis. University of Potsdam, Germany, Alfred Wegener Institute for Polar and Marine Research, Research Unit Potsdam, Germany.

Hogg, E.H. (1993) Decay potential of hummock and hollow Sphagnum peats at different depths in a Swedish raised bog. Oikos 66: 269-278.

Høj, L., Olsen, R.A., and Torsvik, V.L. (2005) Archaeal communities in High Arctic wetlands at Spitsbergen, Norway $\left(78^{\circ} \mathrm{N}\right)$ as characterised by $16 \mathrm{~S}$ rRNA gene fingerprinting. FEMS Microbiol Ecol 53: 89-101.

Jurgens, G., Glockner, F., Amann, R., Saano, A., Montonen, L., Likolammi, M., and Munster, U. (2000) Identification of novel Archaea in bacterioplankton of a boreal forest lake by phylogenetic analysis and fluorescent in situ hybridization. FEMS Microbiol Ecol 34: 45-56.

Khvorostyanov, D.V., Ciais, P., Krinner, G., Zimov, S.A., Corradi, C., and Guggenberger, G. (2008) Vulnerability of permafrost carbon to global warming. Part II: sensitivity of permafrost carbon stock to global warming. Tellus 60B: 265-275.

King, G.M. (1984) Utilization of hydrogen, acetate, and 'noncompetitive' substrates by methanogenic bacteria in marine sediments. Geomicrobiol J 3: 275-306.

Kobabe, S., Wagner, D., and Pfeiffer, E.M. (2004) Characterization of microbial community composition of a Siberian tundra soil by fluorescence in situ hybridization. FEMS Microbiol Ecol 50: 13-23.

MacGregor, B.J., Moser, D.P., Alm, E.W., Nealson, K.H., and Stahl, D.A. (1997) Crenarchaeota in Lake Michigan sediment. Appl Environ Microbiol 63: 1178-1181.

Mangelsdorf, K., Haberer, R.M., Zink, K.G., Dieckmann, V., Wilkes, H., Horsfield, B. (2005) Molecular indicators for the occurrence of deep microbial communities at the JAPEX/ JNOC/GSC et al. Mallik 5L-38 gas hydrate production research well. In: Scientific Results from Mallik 2002 Gas Hydrate Production Research Well Program, Mackenzie Delta, Northwest Territories, Canada Bulletin 585. Dallimore, S.R., and Collett, T.S. (eds). Ottawa, Ontario, Canada: Geological Survey of Canada, Microbiology section, pp. 18-29.

Mann, M.E., Bradley, R.S., and Hughes, M.K. (1999) Northern hemisphere temperatures during the past millennium: inferences, uncertainties, and limitations. Geophys Res Lett 26: 759-762. 
Marchesi, J.R., Weightman, A.J., Cragg, B.A., Parkes, R.J., and Fry, J.C. (2001) Methanogen and bacterial diversity and distribution in deep gas hydrate sediments from the Cascadia Margin as revealed by 16S rRNA molecular analysis. FEMS Microbiol Ecol 34: 221-228.

Morozova, D., and Wagner, D. (2007) Stress response of methanogenic archaea from Siberian permafrost compared to methanogens from non-permafrost habitats. FEMS Microbiol Ecol 61: 16-25.

Oldfield, F., and Alverson, K. (2003) The societal relevance of paleoenvironmental research. In Paleoclimate, Global Change and the Future. Alverson, K.D., Bradley, R.S., Pederson, T.F. (eds). Berlin, Germany: Springer, pp. 1-11.

Oremland, R.S., and Polcin, S. (1982) Methanogenesis and sulphate reduction: competitive and noncompetitive substrates in estuarine sediments. Appl Environ Microbiol 44: 1270-1276.

Overduin, P. (2007) Russian-German Cooperation SYSTEM LAPTEV SEA: the Expedition COAST I. Ber Polarforsch Meeresforsch 550: 1-39.

Overduin, P., Rachold, V., and Grigoriev, M.N. (2008) The state of subsea permafrost in the Western Laptev Nearshore Zone. In Ninth International Conference on Permafrost. Kane, D.L., and Hinkel, K.M. (eds). Fairbanks, AK, USA: Institute of Northern Engineering University of Alaska Fairbanks (2 Vols), pp. 1345-1350.

Peng, J., Lu, Z., Rui, J., and Lu, Y. (2008) Dynamics of the methanogenic archaeal community during plant residue decomposition in an anoxic rice field soil. Appl Environ Microbiol 74: 2894-2901.

Rachold, V., Alabyan, A., Hubberten, H.-W., Korotaev, V.N., and Zaitsev, A.A. (1996) Sediment transport to the Laptev Sea - hydrology and geochemistry of the Lena river. Polar Res 15: 183-196.

Rachold, V., Bolshiyanov, D.Y., Grigoriev, M.N., Hubberten, H.W., Junker, R., Kunitsky, V.V., et al. (2007) Nearshore Arctic subsea permafrost in transition. EOS 88: 149-150.

Ramakrishnan, B., Lueders, T., Dunfield, P.F., Conrad, R., and Friedrich, M.W. (2001) Archaeal community structures in rice soils from different geographical regions before and after initiation of methane production. FEMS Microbiol Ecol 37: 175-186.

Rice, D.D. (1992) Controls, habitat, and resource potential of ancient bacterial gas. In Bacterial Gas. Vially R. (ed.). Paris, France: Éditions Technip, pp. 91-118.

Rivkina, E., Laurinavichius, K., McGrath, J., Tiedje, J., Shcherbakova, V., and Gilichinsky, D. (2004) Microbial life in permafrost. Adv Space Res 33: 1215-1221.

Rivkina, E., Shcherbakova, V., Laurinavichius, K., Petrovskaya, L., Krivushin, K., Kraev, G., et al. (2007) Biogeochemistry of methane and methanogenic archaea in permafrost. FEMS Microbiol Ecol 61: 1-15.

Rivkina, E.M., and Gilichinsky, D.A. (1996) Methane as a paleoindicator of the dynamics of permafrost deposits. Limnol Miner Resour 31: 396-399.

Rivkina, E.M., Gilichinsky, D., Wagener, S., Tiedje, J., and McGrath, J. (1998) Biochemical activity of anaerobic microorganisms from buried permafrost sediments. Geomicrobiol 15: 187-193.

Schönheit, P., Kristjansson, J.K., and Thauer, R.K. (1982) Kinetic mechanism for the ability of sulfate-reducers to outcompete methanogens for acetate. Arch Microbiol 132: 285-288.

Senior, E., Borje Lindstrom, E., Banat, I.M., and Nedwell, D.B. (1982) Sulfate reduction and methanogenesis in the sediment of a Saltmarsh on the East Coast of the United Kingdom. Appl Environ Microbiol 43: 987-996.

Shi, T., Reeves, R.H., Gilichinsky, D.A., and Friedmann, E.I. (1997) Characterization of viable bacteria from Siberian permafrost by $16 \mathrm{~S}$ rDNA sequencing. Microbial Ecol 33: 169-179.

Singh, N., Kendall, M.M., Liu, Y., and Boone, D.R. (2005) Isolation and characterization of methylotrophic methanogens from anoxic marine sediments in Skan Bay, Alaska: description of Methanococcoides alaskense sp. nov., and emended description of Methanosarcina baltica. Int J Syst Evol Microbiol 55: 2531-2538.

Thomsen, T.R., Finster, K., and Ramsing, N.B. (2001) Biogeochemical and molecular signatures of anaerobic methane oxiation in marine sediment. Appl Environ Microbiol 67: 1646-1656.

Vainshtein, M.B., Gogotova, G.I., and Hippe, H. (1995) A sulfate-reducing bacterium from permafrost. Microbiology 64: 436-439.

Wagner, D., Kobabe, S., Pfeiffer, E.-M., and Hubberten, H.-W. (2003) Microbial controls on Methane fluxes from a polygonal tundra of the Lena Delta, Siberia. Permafrost Periglac Process 14: 173-185.

Wagner, D., Lipski, A., Embacher, A., and Gattinger, A. (2005) Methane fluxes in extreme permafrost habitats of the Lena Delta: effects of microbial community structure and organic matter quality. Environ Microbiol 7: 15821592.

Wagner, D., Gattinger, A., Embacher, A., Pfeiffer, E.M., Schloter, M., and Lipski, A. (2007) Methanogenic activity and biomass in Holocene permafrost deposits of the Lena Delta, Siberian Arctic and its implication for the global methane budget. Global Change Biol 13: 10891099.

Watanabe, T., Asakawa, S., Nakamura, A., Nagaoka, K., and Kimura, M. (2004) DGGE method for analyzing 16S rDNA of methanogenic archaeal community in paddy field soil. FEMS. Microbiol Lett 232: 153-163.

Webster, C.R. (2005) Measuring methane and its isotope ${ }^{12} \mathrm{CH}_{4},{ }^{13} \mathrm{CH}_{4}$, and $\mathrm{CH}_{3} \mathrm{D}$ on the surface of Mars with in situ laser spectroscopy. Appl Optics 44: 1226-1235.

Winfrey, M.R., and Zeikus, J.G. (1977) Effect of sulfate on carbon and electron flow during microbial methanogenesis in freshwater. Appl Environ Microbial 33: 275-281.

Zhang, T., Barry, R.G., Knowles, K., Heginbotton, J.A., and Brown, J. (1999) Statistics and characteristics of permafrost and ground-ice distribution in the Northern Hemisphere. Polar Geogr 23: 132-154.

Zhuang, Q., Melillo, J.M., Kicklighter, D.W., Prinn, R.G., McGuire, A.D., Steudler, P.A., et al. (2004) Methane fluxes between terrestrial ecosystems and the atmosphere at northern latitudes during past century: a retrospective analysis with a process-based biogeochemistry model. Global Biogeochem Cycles 18: 3010-3033.

Zimov, S.A., Schuur, E.A.G., and Chapin, F.S., III (2006) Permafrost and the Global Carbon Budget. Science 312: 1612-1613. 